\title{
Literaturoznawstwo jako roz-twarzanie. Problem podwójnego autorstwa w tekstach Tadeusza Rachwała i Tadeusza Sławka
}

ABSTRACT. Bogalecki Piotr, Literaturoznawstwo jako roz-twarzanie. Problem podwóinego autorstwa $w$ tekstach Tadeusza Rachwała $i$ Tadeusza Sławka [The literary science as de-facement. Problem of double authorship in Tadeusz Rachwał and Tadeusz Sławek's texts]. „Przestrzenie Teorii" 7, Poznań 2007, Adam Mickiewicz University Press, pp. 31-46. ISBN 978-83-232177-2-5. ISSN 1644-6763.

The essay is an attempt of rethinking a mode of authorship in literary science discourse of Tadeusz Rachwał and Tadeusz Sławek. Their texts is being compared with G. Deleuze and F. Guattari's method of collective writing and interpreted according to theories of J. Derrida, P. de Man and M. Foucault. Rachwał and Sławek's strategy of double authorship (which is not the same as traditional co-authorship) underlines the impossibility of recognition who is speaking in the text; therefore their collective books may be understood as a kind of performing theses which they contain (e.g. connected with poststructuralist "death of author" or a poet and God's mystical co-writing). Furthermore, double authorship leaves its marks on structure of text. We can see a lot of techniques which make Rachwał and Sławek's texts more complicated, e.g. fragmentary style of writing, using different types of typography and even creating an elements of visual poetry. These experiments and a new way of these texts' being in academic public sphere make them rather ethical than scientific - the ethic qualities and poetic function seem to be more important than the science typical cognitive functions. Because of unceasing underlining a linguistic aspect, the texts of Rachwal and Stawek may be read as examples of rhetorical type of ethic criticism. Not only do they ask about a significance of primary ethical ideas like friendship, community or responsibility, but also about an existence of category of author in literary studies after linguistic turn.

\section{Roz-poczęcie, czyli o roz-mawianiu przy roz-wiązaniu}

Biorąc pióro do ręki, zdaliśmy sobie sprawę, iż dyskurs nie jest łatwym przechodzeniem od linijki do linijki, uniemożliwiającym ogląd pewnej kształtnej, jasno oświetlonej całości; lecz niepostrzeżenie musi prowadzić do „niezupełnie kontrolowanych" poruszeń dłoni, do pisma „o brzydkim charakterze”, do złamania "prostych linii” i marginesów (do „bazgraniny” - scribble - pióra Sterne’a na stronicach Tristrama Shandy). Stąd wywód niniejszej książki nieustannie załamuje się, dopuszcza głosy skądinąd, urywa się [... $]^{1}$.

Kształt dyskursu literaturoznawczego Tadeusza Rachwała i Tadeusza Slawka jest efektem pracy dwojga rąk trzymających jedno pióro.

1 T. Rachwał, T. Sławek, Sfera szarości. Studia nad literaturq i myślq osiemnastego wieku, Katowice 1993, s. 7 . 
We wstępie do jednej z ich wspólnych książek, Sfery szarości - w miejscu szczególnie uprzywilejowanym, jeśli idzie o sygnały metaliterackości nie mógł znaleźć się językowy lapsus: „biorąc pióro do ręki, zdaliśmy sobie sprawę...". Taniec pióra po papierze nie może iść gładko, jeśli trzymają je dwie osoby: prowadzone jest ono raz przez jednego, raz przez drugiego, w roz-stępie, a momentami nawet $w$ roz-kłusie, roz-kłuwającym niczym Nietzscheański młot - jak chcą autorzy -,solidność oświeceniowej konstrukcji bytu"2. Taki szalony taniec, w którym nikt nie prowadzi, nie może przypominać walca czy menueta - w innej części wstępu do Sfery szarości czytamy: „Interesuje nas dyskurs ciemny, próba porozumienia się nie między dwoma dżentelmenami, lecz między jednostką a aniołem, człowiekiem a Bogiem"3. Fakt, że Rachwał i Sławek piszą swoją książkę tak, by nie przypominała ona dialogu „dwóch dżentelmenów" jest o tyle znaczący, że autorzy doskonale zdają sobie sprawę z jego dobrodziejstw: „Prowadząc dyskurs (pamiętajmy o popularności dialogu jako formy wypowiedzi filozoficznej w osiemnastym wieku), mogę dać odpór spotwornieniu i obłędowi"4. Skoro zaś mimo tego nie są dialogiem zainteresowani, godzą się tym samym na „potwornośc”" swoich tekstów i siebie samych jako autorów: „człowiek staje się monstrualny, mówi bowiem nieczysto i niewyraźnie, bełkocze i gulgocze"s.

Pozwoliłem sobie roz-począć od fragmentu jednej tylko książki Rachwała i Sławka ${ }^{6}$, zawiera on bowiem jedną z najciekawszych wykładni ich interesującej i unikatowej w naszym literaturoznawstwie (a i nie tak częstej w ogóle) strategii podwójnego autorstwa. Powiedzmy na wszelki wypadek: nie ma ono wiele wspólnego $\mathrm{z}$ pracą zespołu badaczy nad wybranym zagadnieniem, a równie daleko jest mu do takich gatunków obdarzanych od pewnego czasu funkcją poznawczą i z tego powodu możliwych jako literaturoznawcze, jak wywiad, konferencja czy dyskusja. W nich bowiem, choć publikację może sygnować kilka nazwisk, każda

\footnotetext{
2 Tamże.

3 Tamże.

4 Tamże, s. 139.

5 Tamże.
}

${ }^{6}$ Oprócz niej wymienić należy: T. Rachwał, T. Sławek, Maszyna do pisania. O dekonstruktywistycznej teorii literatury Jacques'a Derridy, Warszawa 1992 oraz D. Jarrett, T. Rachwał, T. Sławek, Geometry, Winding Paths and the Mansions of Spirit. Aesthetics of Gardening in the Seventeenth and Eighteenth Centuries, Katowice 1997. Pozostałe wspólne książki Rachwała i Sławka podzielone są na „osobne” teksty (sygnowane pojedynczymi nazwiskami), choć i one zawierają interesujące eksperymenty wymierzone w problem autorstwa tekstu literaturoznawczego (zob. np. Aneks do: Tekst, (czytelnik), margines, red. W. Kalaga, T. Sławek, Katowice 1988, s. 184-220, nawiązujący swą budową do dramatu, w którym każdy autor odgrywa przypisaną mu „rolę tytułową”, np. Rachwał jest „Tekstem”, a Sławek „Nawiasem”). 
osoba wypowiada się w swoim imieniu, natomiast w wypadku książek Rachwała i Sławka nigdy nie jesteśmy pewni, kto mówi - wiemy jedynie, że fragment, który czytamy, został napisany. „Roz-poczynając” wejściową intuicję metaautorską od słów „Biorąc pióro do ręki, zdaliśmy sobie sprawę...”, autorzy biorą „roz-brat” z tradycyjnie pojmowaną kategorią autora jako jednostkowej przyczyny sprawczej tekstu. Gest ten powtórzy Sławek dwa lata później, we wstępie do Literary voice. The calling of Jonah, książki napisanej na identycznych zasadach „podwójnego autorstwa" z Donaldem Weslingiem:

Our focal idea about literary voice has found one example in our own work. Collaborating as a method of writing underlines, indeed exaggerates, the impossibility of knowing who is speaking. Since our definition of literary voice is the impossibility of knowing who is speaking, we hope to have performed what we have defined?

Niemożność identyfikacji „głosu” mówiącego do nas przez pismo cechuje każdy tekst; czy w takim razie „podwójne autorstwo” Rachwała i Sławka czy też Weslinga i Sławka nie jest jedynie kolejną manifestacją tego dobrze znanego faktu? Mogłoby tak być, ale skoro performance cechować ma niepowtarzalność, zbyt monotematyczny bylby performer ze Sławka: współautora nie tylko czterech „podwójnych książek", ale i paru płyt, w których na podobnych zasadach jego głos „roz-mawia” z kontrabasem Bogdana Mizerskiego ${ }^{8}$. Zwróćmy więc uwagę na coś innego, o czym wyraźnie mówi wstęp do Sfery szarości, a mianowicie na moment „niezupetnie kontrolowanych poruszeń dłoni”. Można by odpuścić i nie zastanawiając się, czyja ręka im ulega, skonstatować, że istotniejsza jest powstała w ten sposób trudna w lekturze „bazgranina” (termin ten odsyła nas do fascynacji Rolanda Barthes'a, dla którego każde pisanie stanowiło rodzaj "bazgrania", podobnego raczej malarstwu niż mowie). Można jednak tak odpowiedzieć na pytanie płynące ze wstępu: „niekontrolowane poruszenia" muszą być skutkiem owego wspólnego sięgnięcia po pióro, od początku budzącego nasze zdziwienie. Mówiąc inaczej: kształt dyskursu Rachwała i Sławka rozpatrywany być powinien jako element strategii podwójnego autorstwa. Czytając w ten sposób, wycho-

${ }^{7}$ D. Wesling and T. Sławek, Literary voice. The calling of Jonah, State University of New York Press, Albany 1995, p. x.

8 Wszystkie wydane jako CD w wytwórni B. Mizerskiego „Off-records”: De-konstrukcje. Trzy eseje na glos $i$ kontrabas (1998), Podróż mistyczna z Nysy do Barda Ślaskiego (2000), Rzeczy/Teraz (2001), Żaglowiec Nietzsche (2002). Para Slawek-Mizerski występowała ponadto $\mathrm{z}$ innymi projektami o podobnym charakterze, $\mathrm{z}$ których wymienić należy ostatni - Drzewo aniołów. Życie, śmierć Williama Blake'a (premiera: 24 V 2006) - gdzie do recytującego głosu i dźwięku kontrabasu dołączył sopran J. Kościuszczyk-Jędrusik oraz instalacja wideo Ewy Sataleckiej. 
dząc z tekstu na okładkę książki opatrzoną podwójną sygnaturą, podejmujemy się niełatwego zadania połączenia porządku tekstu z rzeczywistością pozatekstową - instytucją, która umożliwiła i w odpowiedni sposób usankcjonowała podwójne autorstwo. Jak mniemam, lektura taka wpisuje się do pewnego stopnia w granice postulowanej przez Danutę Ulicką „antropologii literaturoznawstwa”, dla której projektu przypadek tekstów Rachwała i Sławka stanowić może inspirujące wyzwanie ${ }^{9}$.

Jeśli jednak amorficzność tego literaturoznawstwa (o której więcej za moment) jest zamierzona, musi pociągać za sobą zmianę funkcji tekstu i inaczej projektować jego teleologię. Aby powrócić do tanecznej metaforyki: różnica między potwornym „roz-krokiem”, w jakim utknęli w tańcu nie chcący zsynchronizować ruchów Rachwał i Sławek, a płynnym, przeźroczystym krokiem tancerzy-dżentelmenów jest mniej więcej taka, jak różnica pomiędzy roz-mową a z-mową ${ }^{10}$. Metafora dialogu jako tańca wskazuje na moment pewnej przemocy, będący efektem wcześniejszej z-mowy: taniec tylko pozornie opiera się na spontanicznym porozumieniu, zaś w rzeczywistości, jeśli partnerka nie podporządkuje się partnerowi, a ten nie będzie respektował określonych zasad (rytm, kroki, figury itd.), tancerzom zaczną plątać się nogi ${ }^{11}$. Podziwiając strukturę dialogów

9 Zob. D. Ulicka, Funkcja poznawcza "literatury" $i$ "wiedzy o literaturze” (tezy do przysztej antropologii literaturoznawstwa), „Teksty Drugie” 2005, nr 5.

${ }^{10}$ Zdaję sobie sprawę, że prowadząc wywód w tę stronę, nie sposób wyczerpać bogatej problematyki związanej z pojęciem „dialogu" i kwestią „dialogiczności”. Należałoby koniecznie zwrócić się do samego Platona i znanego rozróżnienia na maieutykę i elentykę (zob. np. I. Krońska, Sokrates, Warszawa 1985, s. 84-94), jednak na tym tle $z$-mowę rozpoznać można zarówno w jednej, jak i w drugiej, zaś roz-mowa byłaby rodzajem afirmacji negatywności postępowania elentycznego i związanej z nim ironii. Bardziej przydatne byłoby tu przywołanie myśli Michaiła Bachtina, wychodzącej od (później zmodyfikowanego) rozróżnienia na „dialog filozoficzny", w którym „wielość głosów jest jednak tłumiona przez idę"” i na „dialog Dostojewskiego", na którego postać wpłynęły "dialog Hioba oraz dialogi niektórych ewangelistów" (nie na darmo Rachwal i Slawek piszą więc 0 „próbie porozumienia się między jednostką a aniołem"). Tak jak w analizach Bachtina, roz-mowy autorów Sfery szarości „zmierzają do rozpisania tematu na wiele różnych głosów”, „o żadnej syntezie nie może być mowy”, a chodzi raczej o „zderzenie wzajemnego oddziaływania głosów na siebie” (M. Bachtin, Z rozdziału "Dialog u Dostojewskiego" (1929), w: tegoż, Estetyka twórczości stownej, przeł. D. Ulicka, Warszawa 1986, s. 282283). Niewątpliwie postać Bachtina w dużej mierze wpłynęła na koncepcję podwójnego autorstwa Rachwała i Sławka (dość wspomnieć, że Bachtin wraz z Wołoszynowem i Miedwiediewem poprzedzają ich na tym polu), jednak sami autorzy rzadko odwołują się wprost do jego/ich pism (częściej zaś do Deleuze’a i Guattariego, których patronat niech usprawiedliwi mnie z prób „tworzenia pojęce”, takich jak powyższe powołanie do życia „z-mowy”).

11 Pisze Gadamer, ze taki typ rozmowy, który pozwoliłem sobie tutaj nazwać „z-mowa": „traci życie w momencie, gdy ten drugi nie nadąża i zamiast odpowiedzieć musi zapytać: Czy możesz powiedzieć to jeszcze raz? Wówczas kończy się charakterystyczny, niemal tanecznie lekki krok, jakim rozmowa spontanicznie się porusza, gdy sprzyjają jej wiatry". 
filozoficznych, nie możemy nie zauważać, że są one ukierunkowane i służą skutecznej prezentacji prawdy, którą filozof zna już przed wysłuchaniem argumentów interlokutora. W tak rozumianym dialogu „Sokrates pyta tylko dlatego, że zna odpowiedź, i słucha tylko dlatego, że wie"12, a dialog nie polega na spotkaniu dwóch indywidualności, ale na stopieniu horyzontów, po którym wszystko musi iść już gładko, tanecznym krokiem.

Tymczasem wielkość Sokratesa polega na tym, że uprawiając dialog (uprzednio zmówiwszy się z samym sobą, co do swoich celów i tylko dzięki temu mogąc uprawiać go jak uprawia się pole - systematycznie i planowo), potrafi zająknąć się i roz-począć roz-mowę. Roz-mowa zaś idzie jak po gruzie, prowadzi do roz-padu wyobrażeń i przekonań, $z$ jakimi podchodzą do niej rozmówcy, odżywia ją ruch odśrodkowy, nigdy nie daje wyniku - jest wiecznym roz-ruchem, a zniecierpliwieni kibice nie doczekują się inaugurującego mecz gwizdka, po którym wszystko musi już dać się sprowadzić do trzech ewentualności: zwycięstwo, porażka, remis. Nie godzący się na jednoznaczne rozstrzygnięcia, roz-kraczeni w swych rozciągających ćwiczeniach, Rachwał i Sławek uważnie wsłuchują się w głosy innej, grającej w jednej drużynie pary, równie usilnie zwalczającej pstrą gadaninę. Deleuze i Guattari piszą wprost:

Filozofia brzydzi się dyskusjami. Ma coś innego do zrobienia. Debatowanie jest dla niej nieznośne, bynajmniej nie dlatego że jest ona zbyt pewna siebie; przeciwnie, to właśnie niepewność wiedzie ją na inne, bardziej samotne drogi ${ }^{13}$.

Roz-pędziwszy się, Deleuze i Guattari „wbiją bramkę” Sokratesowi:

W rzeczywistości Sokrates stale uniemożliwiał jakąkolwiek dyskusję, zarówno w ścisłej formie agonu pytań i odpowiedzi, jak również w pojemnej formie rywalizacji mów. Przyjaciela zamienił w przyjaciela jednego pojęcia i to zdecydowanie monologicznego, eliminującego stopniowo wszystkich rywali ${ }^{14}$.

Zawieszając początek „monologicznej” rywalizacji, jaką łatwo stać się może zarówno mecz, dialog, jak i prezentacja badawczego dorobku, rozbudowując przestrzeń umożliwiającą dystans, a dzięki niej roz-suwając się i rezygnując $z$ utopijnego dążenia do osiągnięcia pozbawionego elementu przemocy konsensusu - dają Rachwał i Sławek świadectwo przy-

Zob. H.G. Gadamer, Wiersz i rozmowa. Rozważania nad próbką tekstu Ernsta Meistra (1988), w: tegoż, Poetica, przel. M. Łukaszewicz, Warszawa 2001, s. 131.

12 M.P. Markowski, Stuchanie i nierozumienie, w: tego $\dot{z}$, Pragnienie $i$ bałwochwalstwo. Felietony metafizyczne, Kraków 2004, s. 157.

13 G. Deleuze, F. Guattari, Co to jest filozofia? (1991), przeł. P. Pieniążek, Gdańsk 2000 , s. 37.

14 Tamże. 
jaźni, którą Deleuze i Guattari nazwaliby „wielogłosową”, a której kształt - jak uczy zakończenie znanego tekstu Derridy - „może się zapowiadać, taka jest konieczność, za każdym razem, gdy chodzi o narodziny, tylko w postaci niepostaciowej, w bezkształtnym, niemym, niemowlęcym i budzącym strach kształcie potworności"15. Roz-poczynając pisanie, Rachwał i Sławek nie zwiastują żadnego innego narodzenia: pisząc na wstępie o „bazgraninie”, „nierównym rytmie” pisma, „złamaniu prostych linii”, otwierają się na to, co „budzi strach” (zdecydowanie woleliby Sokratesa potwornego $\mathrm{z}$ monstrualnym nosem i uszami niż Sokratesa z jego zacnego marmurowego wizerunku reprodukowanego $w$ podręcznikach). „Postacią pojęciową"16 autora ich tekstów jest monstrum: jak inaczej bowiem nazwać coś obdarzone czterema rękoma, dwiema głowami i jednym piórem? Roz-poczynając pisanie, Rachwał i Sławek poczynają potwora, a miejscem, w którym przyjmują ten trudny poród, miejscem oczekiwania na roz-wiązanie (więzów z-mowy), są oni sami.

\section{Roz-dziawianie, czyli roz-prawa o metodzie}

Nie rozmawiajcie ze sobą, nie rozmawiajcie tylko ze sobą; niech w każdej rozmowie jest coś, co nie jest wami, co nie zna chłodnego zajazdu waszej gramatyki, coś, co bełkocze, ślini się, coś, co umiera z rozdziawionymi ustami. Coś, co jest glodne ${ }^{17}$.

Wejścia do Księgi strzegą cztery milczące postacie spoglądające z wysokich postumentów. Twarde słowa jednego ze Strażników, zastygłe w kamiennej nieodwołalności, proklamują zniesienie „obowiązku łamania sobie głowy nad tym, co właściwie myśli autor filozoficzny, piszący stylem niejasnym”, głosząc: „Odgadywanie jego myśli tylko wtedy przedstawiać będzie rzecz godną wysiłku, jeśli skądinąd nabyliśmy przekonania, że myśli jasno, że więc niejasność stylu pochodzi w danym wypadku ze skażenia tekstu albo z pośpiechu w spisywaniu dzieła. Jeżeli nie mamy tego przekonania, wtedy możemy spokojnie przyjąć, że autor nie umiejący myśli swych wyrazić jasno nie umie też myśleć jasno, że więc

15 J. Derrida, Struktura, znak i gra $w$ dyskursie nauk humanistycznych (1966), w: tegoż, Pismo i różnica, przeł. K. Kłosiński, Warszawa 2004, s. 504.

16 W koncepcji Deleuze'a i Guattari'ego postacie pojęciowe „ukazują absolutne terytoria, deterytorializacje i reterytorializacje myślenia" (tychże, Co to jest..., s. 79), pełnią więc rolę uprzednią wobec autora, stąd „postać pojęciowa nie jest przedstawieniem filozofa, wręcz odwrotnie: filozof to tylko osłona głównej postaci pojęciowej i wszystkich pozostałych, które są orędownikami, prawdziwymi podmiotami jego filozofii" (tamże, s. 73-74).

17 T. Sła wek, Podróż czterech męźów z Nysy do Barda Ślaskiego, Pszczyna 2000, s. 22. 
myśli jego nie zasługują na to, by silić się na ich odgadywanie"18. Idąc za słowami filozofa, musielibyśmy rzucić w kąt książki Rachwała i Sławka: niejasność ich stylu nie pochodzi ani ze „skażenia tekstu” (jak pamiętamy, sami autorzy skazują swoje dzieło na „bazgraninę”), ani z „pośpiechu w spisywaniu" (autorom przyświeca raczej Nietzscheański postulat „przeżuwania”), a jednak ostatnią rzeczą, jaką można powiedzieć o ich książkach, jest ,jasność" stylu. Mamy tu do czynienia z najbardziej wyrazistym w naszym literaturoznawstwie zespołem technik ,zaciemniających" przekaz.

W cytowanej już Sferze szarości autorzy używają co najmniej ośmiu kombinacji czcionek i odstępów, paru rodzajów wcięć, przynajmniej czterech sposobów cytacji oraz takich skierowanych przeciw linearności tekstu technik jak prowadzenie wywodu w dwóch równoległych kolumnach czy inkrustowanie tekstu ramkami z cytatami, często bardzo luźno związanymi z tekstem głównym. Czasami część tekstu „wystaje” poza nie, a prawie zawsze ramki roz-bijają całości zdaniowe tekstu głównego zamiast sytuować się po kropkach lub pomiędzy akapitami ${ }^{19}$.

Wizualne zróżnicowanie poszczególnych partii tekstu cechuje także książkę Geometry, Winding Paths and the Mansions of Spirit... z 1997 roku, napisaną we trójkę z Davidem Jarrettem, zaś w wydanej najwcześniej (w 1992) Maszynie do pisania również znaleźć można ramki-dygresje, cytat z Derridy umieszczony został już na stronie tytułowej, zaś na końcu rozczlonkowane nazwisko filozofa wprzęgnięte zostało $w$ rodzaj gry, którą nazwać moglibyśmy poezją konkretną. Są to zabiegi o tyle ważne, że nieprzypadkowe i jak się wydaje - w istotny sposób wpływające na przekaz ${ }^{20}$. To roz-pisanie „materialnej strony” tekstów Rachwała

${ }^{18} \mathrm{~K}$. Twardow ski, O jasnym $i$ niejasnym stylu filozoficznym (1919), w: tegoż, Wybrane pisma filozoficzne, Warszawa 1965, s. 348. Fragment umieszczony na „Kolumnadzie Filozofów" w gmachu Biblioteki Uniwersyteckiej w Warszawie.

19 Wszystko to jest, rzecz jasna, Derridiańskiej proweniencji, by przypomnieć Glas książkę ważną dla pomysłu podwójnego autorstwa także z powodu jej pozornej „dwugłosowości” (Hegel, Genet), a w istocie „trójgłosowości” (Derrida), a nawet „wielogłosowości” (cytaty, przytoczenia etc.). W interpretacjach Glas pojawia się stanowisko uznające tekstową - by pozostać już przy tym słowie - „bazgraninę” za kolejny „podmiot” tej książki, a więc za kolejnego partnera „roz-mowy”. Rzeczywiście, „materialność” pisma nie jest dla Derridy (jak również dla Rachwała i Slawka) jedynie narzędziem, ale przede wszystkim koniecznością (do czego jeszeze powrócimy). O roli typografii por. w Glas: „Through the structure of two columns, the interruptions into the columns, the different print sizes and styles, the parenthesized interjections and rem(a)inders, it is the textual surface, the textuality of the text, which becomes the subject of this text as much as Hegel, or Genet, or Derrida". J. Brannigan, We have nothing to do with the literature: Derrida and Surrealist Writing, w: The French Connections of Jacques Derrida, ed. J. Wolfreys, R. Robbins, J. Brannigan, New York 1999, p. 60.

20 Zob. T. Sławek, Między literami. Szkice o poezji konkretnej, Wrocław 1989. 
i Sławka skorelowane jest $\mathrm{z}$ charakterystycznym wewnętrznym napięciem stylistycznym, pozwalającym na łatwą identyfikację ich książek na tle innych opracowań literaturoznawczych. (Nie miejsce tu na dokładniejszą analizę wyrazistego stylu Rachwała i Sławka, z pewnością jednak wiedzą oni, że styl „powinien być więcej niż jeden. Przynajmniej dwie ostrogi - wówczas się opłaci"21). Rozpatrywany w tym świetle pomysł podwójnego autorstwa jawić się może jako jedna $\mathrm{z}$ wielu technik służących roz-warciu neopozytywistycznej formuły tekstu literaturoznawczego (czy szerzej: naukowego), którą - nie wiedzieć do końca czemu - uznaliśmy za obligatoryjną.

Nie dosyć na tym: dom tekstu, którego granice zakreśla język, okazuje się być „chłodnym zajazdem gramatyki”; stąd postulat Sławka - według którego w każdej rozmowie powinno znaleźć się „coś”, co, choć głodne, od tego zajazdu woli trzymać się jak najdalej - daje się czytać jako postulat poszukiwania wyjścia $\mathrm{z}$ tekstu. Skoro jednak wiemy, że takiego wyjścia nie ma lub przynajmniej, że nie znaleźliśmy go do tej pory, jedynym sposobem na naruszenie murów „więzienia” gramatyki jest próba oddania temu „czemus” głosu. Sławek nie ma jednak wątpliwości, że owo "coś” nie jest dobrym mówcą („bełkocze, ślini się"), a nawet więcej: że przywołanie tego „czegoś” jest przywołaniem śmierci („umiera z rozdziawionymi ustami"). A jednak przywołuje, a "ono" zjawia się rzeczywiście w postaci językowego widma: w postaci cytatu, parafrazy, aluzji (poemat „Podróż czterech mężów z Nysy do Barda Sląskiego”, z którego pochodzi omawiany fragment, prawie $\mathrm{w}$ całości utkany jest $\mathrm{z}$ parafraz tekstów Blake'a, Angelusa Silesiusa, Swedenborga i Böhmego; podobną strukturę mają książki Rachwała i Sławka).

Chciałbym zwrócić tu uwagę na dwie kwestie. Pierwszą z nich jest szczególna rola słów obcych w tekstach Rachwała i Sławka, które rzadko kiedy w przejrzysty sposób służą prezentowanej tam argumentacji. Częściej wydają się one jeszcze bardziej komplikować sprawę: „roz-łamując” porządek wywodu (taka jest rola wspomnianych ramek z cytatami), prowadzą do "roz-dziawiania ust” jego autorów, którzy muszą zawiązywać „roz-erwany” w ten sposób splot myśli na nowo. Można widzieć przyczynę tego permanentnego „roz-rywania” właśnie w podwójnym autorstwie: żaden z autorów nie jest ani przez chwilę „sam”, drugi nie opuszcza go ani na krok i w każdej chwili zaprosić może do tekstu nowego kłopotliwego gościa; zasadą funkcji autora u Rachwała i Sławka byłaby więc Derridiańska gościnność, do której zresztą wielokrotnie się oni odwołują. Drugim wartym namysłu momentem jest sam gest przywoływania cze-

21 J. Derrida, Ostrogi. Style Nietzschego (1978), przeł. B. Banasiak, Gdańsk 1997, s. 86. 
goś, co - jak wiemy - przynosi śmierć lub nawet jest śmiercią samą, a w którym to geście nie możemy nie rozpoznać prozopopei. Nie możemy zapomnieć tė̇, że de Man łączy ją z autobiografią, na co „wskazuje wyraźnie etymologia nazwy tego tropu, prosopon poien, przydawać maskę lub oblicze (proposon)"22. Czytając artykuł de Mana, Rachwał i Sławek wydobywają z niego myśl: „różnica między mową pogrzebową a autobiografią nie tylko nie istnieje, ile jest niedecydowalna (undecidable)"23. Jeśliby chcieć wyczytać z tekstów Rachwała i Sławka jakąś naukę dotyczącą ich metody, przydatna mogłaby okazać się ucieczka w parafrazę: różnica pomiędzy ich literaturoznawstwem a autobiografią nie tyle nie istnieje, ile jest niedecydowalna.

Chcąc rozpatrywać podwójne autorstwo i strukturę tekstu łącznie, jako pewną strukturę, natrafiamy na paradoks przypominający działanie prozopopei („nadawanie i pozbawianie oblicza, twarz i od-twarzanie"24). Stawką strategii Rachwała i Sławka jest zacieranie autorstwa, a jednak autorski idiom tak bardzo manifestuje się na płaszczyźnie stylu, kompozycji i „materialności” książki, że nie sposób wziąć go w nawias. Napięcie to ujawnia charakter gry, jaką prowadzą Rachwał i Sławek. Polega ona na "roz-twarzaniu" instancji autora (stąd nadwątlanie prawa linearności, brak wyrazistych, jasno-wykładalnych tez, mnogość cytatów i parafraz, nie zawsze określonego wprost pochodzenia itp.) i autorytetu (skomplikowanie mechanizmu identyfikacji ustaleń badawczych $\mathrm{z}$ osobą badacza, komplikacja prawa odpowiedzialności za słowo, praw autorskich czy sposobu cytowania i odnoszenia się "do", inna ranga "my" tekstu naukowego itd.) przy jednoczesnym nadawaniu powstającym tekstom latwo identyfikolwanych znamion „autorskości” (tutaj wszystko, co składa się na ich styl, łącznie z zabiegami wizualnymi, a także $\mathrm{z}$ takimi cechami literaturoznawczego „idiolektu”, jak obsesyjne powracanie do tych samych autorów, ze strony Sławka przede wszystkim do Blake'a, Thoreau i Nietzschego), a więc przemieszczaniem owej „twarzy” na inny poziom (stąd mówię nie o od-twarzaniu, ale o roz-twarzaniu, w którym zawarty jest ruch nowego roz-mieszczania „twarzy”).

Mechanizm ten wzywa do uważniejszego przyjrzenia się tekstom Rachwała i Sławka; być może „podwójne autorstwo” jest znaczące nie tylko jako manifestacja praw dekonstrukcji, ale również jako próba kreacji innej formy modalności tekstu literaturoznawczego? Wydaje się, że do tej pory nie podjęto zmierzającej w tym kierunku refleksji nad po-

22 P. de Man, Autobiografia jako od-twarzanie (1979), przeł. M.B. Fadewicz, „Pamiętnik Literacki" LXXVII 1986, z. 2, s. 314.

${ }^{23}$ T. Rachwal, T. Sławek, Sfera..., s. 56.

${ }^{24}$ P. de Man, Autobiografia..., s. 314. 
dwójnym autorstwem, traktując je przede wszystkim właśnie jako „przyjęcie pisarskiej strategii” Derridy25. Stąd M.P. Markowski zamknąć mógł całą kwestię w nieco ironicznym nawiasie: „[...] Tadeusza Sławka i Tadeusza Rachwała (których dalej, nie będąc do końca świadom, gdzie między nimi przeprowadzić granicę, nazywać będę Sławkiem Rachwałem)". Wykorzystując deminutywność nazwiska Tadeusza Sławka i sugerując odczytywanie go jako zdrobnienia imienia Sławomir (na tym polega ochrzczenie autorów nowym imieniem „Sławek Rachwał”), Markowski zagłaskal jednak potwora, czyniąc z niego maskotkę ${ }^{26}$. Gest ten jest o tyle znaczący, że dotyczy także zawartości Maszyny do pisania, którą Markowskiemu zbyt chyba łatwo udało się przeciwstawić komentarzom Bogdana Banasiaka, wpisując je w parę opozycji, tudzież schematów dyskursywnych. Jeśli autor - to imię (choćby zdrobnione) i nazwisko; jeśli u Banasiaka teksty Derridy są „filozoficzne” - to dla Sławka Rachwała muszą być one „literaturą". Nie miejsce tu na wikłanie się w spory o interpretację pisarstwa Derridy; chciałbym jedynie zwrócić uwagę, że fakt istnienia "ostentacyjnie wybranej" podwójnej sygnatury autorskiej domaga się bycia wziętym pod uwagę, jeśli chodzi o interpretację tekstu ustanowionego w ten sposób. Oznacza to mniej więcej tyle, że porządek dyskursu Maszyny do pisania zawłaszczył również instytucjonalną sferę książki - problem autorstwa jest w dużej mierze problemem politycznym i, jak powiada Foucault, wziął się z konieczności prawnego rozwiązania kwestii odpowiedzialności na napisane słowo ${ }^{27}$ a więc, że Maszyna generuje inną modalność istnienia tekstu literaturoznawczego niż typ tekstu autorskiego, do którego jesteśmy przyzwyczajeni. Pisze Foucault: „Sposób, w jaki [wypowiedzi - P.B.] odnoszą się do relacji społecznych, jest o wiele bardziej widoczny w grze funkcji autora i jej przekształceniach niż w zawartych w nich tematach i pojęciach"28.

Gra, w którą grają Rachwał i Slawek powinna być odczytywana także w tym świetle: lektura nie może ograniczać się do podejmowanej w ich książkach tematyki, ale musi być także społeczna, czy też - jeśli wolimy

25 T. Komendant, Czy ujrze postmodernizm w Warszawie?, „Res Publica Nowa" 1993, nr 9, s. 70. Cyt. za: M.P. Markow ski, Efekt inskrypcji. Jacques Derrida i literatura (1997), Kraków 2003, s. 56.

${ }^{26}$ M.P. Markowski, Efekt..., s. 56. Pomijam tu wcześniejszą chronologicznie recenzję Maszyny do pisania z "Tekstów”, w której Markowski rozwijał swój koncept jeszcze bardziej wirtuozersko, co było oczywiście przejawem zamierzonej strategii marketingowej.

27 „Teksty, książki, wypowiedzi zaczęły mieć autorów [...] w momencie, gdy autora można było ukarać za wypowiedź, którą odbierano jako przekroczenie granic". M. Foucault, Kim jest autor? (1969), przel. M.P. Markowski, w: M. Foucault, Szaleństwo i literatura: powiedziane, napisane, wyb. i oprac. T. Komendant, Warszawa 1999, s. 207.

28 Tamże, s. 218. 
- polityczna czy ideologiczna. Sporo zawdzięczając przemianom kulturowo-społecznym drugiej połowy XX wieku (czego znakiem są ich długie włosy, „młodzieżowy” sposób ubierania się i zamiłowania do muzyki rockowej), autorzy wydają identyfikować się z postawą zaprezentowaną przez H.D. Thoreau w jego Obywatelskim nieposłuszeństwie ${ }^{29}$. Tak, jak strategią Thoreau była próba zmiany istniejącej sytuacji politycznej nieludzkim sposobem, poprzez odebranie sobie przywileju głosu i swego rodzaju regres $\mathrm{w}$ „Zwierzęcość”, tak pomysł na literaturoznawstwo Rachwała i Sławka odbywa się na drodze roz-bierania wiedzy o literaturze z „twarzy”. „Ludzkie” (zinstytucjonalizowane) literaturoznawstwo wyraźnie tu przeszkadza i krępuje pozaetykietowe roz-kroki tańca, który Rachwał i Sławek roz-poczęli z całą świadomością tego, że sytuują się poza "salonem" i na peryferiach, i że próbując skonstruować nową modalność kategorii autora tekstu o literaturze, biorą w nawias swoje „zasługi” na tym polu. Ale stawką jest możliwość „roz-dziawienia” ust, którą to obce "cos", funkcjonujące od kilkunastu lat w naszym literaturoznawstwie, ma szansę przywołać, a także (bo to kolejny aspekt tekstów Rachwała i Sławka) zrobić miejsce dla takiej roz-mowy o rzeczach ważnych (ludzkich, arcyludzkich), która dzięki lekcji dekonstrukcji nie wspierałaby się na prawach opozycji i wykluczania.

\section{Roz-twory, czyli o efektach roz-twarzania}

Przyjaźń jako kontr-związek sprzeciwia się wszelkim kompromisom i koalicjom, ale wystrzega się wojen; jest to relacja niespokojnego pokoju, konfliktu pozbawionego znamion agresji i wojny ${ }^{30}$.

Przedmiotem literaturoznawstwa są utwory literackie. Wiemy jednak, że ułudą jest istnienie ontologicznej granicy pomiędzy utworem a literaturoznawczym tekstem mu poświęconym, który w takim razie zawsze jawić się musi jako po-twór: hybryda, na której ciele zaszczepia się nieskończona mnogość nieskończonych odczytań możliwych dzięki językowi ${ }^{31}$. „Roz-twarzając po-twory”, jakimi są i muszą być ich teksty, "roz-bierając” je z tego, co nazwaliśmy literaturoznawczą „twarzą”, uzy-

${ }^{29}$ Zob. H.D. Thoreau, Obywatelskie niepostuszeństwo (1849), w: tegoż, Życie bez zasad. Eseje, przeł. H. Cieplińska, Warszawa 1983, s. 195-229.

${ }^{30}$ T. Slawek, U-bywać. Człowiek, świat, przyjaźń w twórczości Williama Blake'a, Katowice 2001, s. 142.

${ }^{31}$ Dla Derridy potwór to "figura złożona z innorodnych organizmów zaszczepionych na sobie". Cyt. z: J. Derrida, Points de suspensious. Entretiens (1992) za: M.P. Markow ski, Efekt..., s. 364 . 
skują Rachwał i Sławek pewien nowy, choć trudny do analizy, stan skupienia, który nazwać należałoby w tym miejscu roz-tworem. Za-sadą powstawania roz-tworów jest roz-pisanie literaturoznawczego sztafażu na dwa pióra lub, jeśli wolimy, na dwie ręce trzymające pióro, czyli wysunięcie na pierwszy plan momentu roz-mowy - owego „kontr-związku”, w efekcie którego tekst zyskuje konsystencję roz-tworu intuicji, poglądów, przekonań, historii, doświadczeń i wspomnień obydwu autorów, a w którym żadna teza nie przyjmuje „koalicyjnej” postaci „ciała stałego”. Zamiast ruchu dośrodkowego, który ożywia każdy tekst aspirujący do „naukowości”, mamy tu ruch odśrodkowy, który ,jasności” jednoznacznych eksplikacji tekstu naukowego sprzeciwia się nie $\mathrm{z}$ zasady, ale w imię „roz-tworu”, jaki musi zaistnieć jako efekt przyjaźni „roz-mówców". Wydaje się, że dzięki temu literaturoznawstwo Rachwała i Sławka sytuuje się pomiędzy ekstremum idiomatyczności (eksponowaniem indywidualności badacza) a ekstremum instytucjonalności (uznaniem językowego, społecznego, historycznego itd. zdeterminowania wszelkich jego poczynań). Tę pierwszą skrajność niweczy konieczność uzgadniania jednostkowej intuicji z drugim autorem, który musi podpisać się pod tekstem swoim nazwiskiem - aby więc nie stracić twarzy, będzie negocjował swoje racje i swój punkt widzenia. Determizm instytucjonalności jest natomiast roz-bijany przez samą naturę owych negocjacji: ponieważ nie da się pisać razem, w jednym momencie (porządek pisania, jak i porządek lektury, jest linearny), zawsze do głosu dochodzić będzie styl czy, jeśli wolimy, rytm indywidualny, „poruszenia” piszącej właśnie ręki (stąd też rozbijanie dyktatu linearności poprzez stosowanie rozmaitych technik typograficznych). Teksty Rachwała i Sławka nie upadają w efekcie ani w iluzję efekciarskiej oryginalności („wolno mi wszystko powiedzieç"), ani w bezosobowość literaturoznawczej powtarzalności („nie jestem w stanie dodać nic od siebie").

Wprowadzenie kategorii roz-tworu wydaje się potrzebne o tyle, o ile pozwala odróżnić strategię Rachwała i Sławka od niewątpliwie bardzo ważnego dla nich wzorca, jakim jest pisarstwo Deleuze'a i Guattariego. Filozoficzną podstawą wspólnego autorstwa tych drugich jest Deleuzjańska krytyka strukturalizmu: „Strukturalizm zgoła nie jest myśleniem, które znosi podmiot, ale myśleniem, które systematycznie go rozrzuca i rozdziela, które zaprzecza tożsamości podmiotu, które go rozkłada i przesuwa $\mathrm{z}$ miejsca na miejsce, ukazując podmiot nomadyczny, złożony $\mathrm{z}$ ujednostkowien, ale bezosobowych, lub z osobliwości, ale przedindywidualnych”32. Wskazując na niewystarczalność „pojęcia podmiotu”, które

32 G. Deleuze, Po czym rozpoznać strukturalizm?, przeł. S. Cichowicz, w: Drogi wspótczesnej filozofii, red. M. Siemek, Warszawa 1978, s. 322. Cyt. za: M. Herer, Gilles Deleuze. Struktury - maszyny - kreacje, Kraków 2006, s. 155. 
„bardzo straciło na znaczeniu na korzyść osobliwości przed-indywidualnych i bezosobowych indywidualności" ${ }^{3}$, Deleuze i Guattari - jak pisze Michał Herer - „w decydującym momencie wprowadzają na scenę postać [...] „strukturalistycznego bohatera”, jak go nazywał Deleuze. Jest on podmiotem”, którego „ruchliwość jest niezrównana”, co „zapewnia rozpad struktury"34. Taki punkt wyjścia umożliwia autorom Kapitalizmu $i$ schizofrenii „radykalną zmianę perspektywy dotyczącej samego ujęcia podmiotowości”, które rozwinięte zostanie w "całkowicie pozytywną i oryginalną koncepcję pragnienia” ("maszyny pragnienia”) ${ }^{35}$. Dzięki niej mogą oni otworzyć Kłqcze prowokacyjnym: „Dlaczego zachowaliśmy nasze nazwiska? Z przyzwyczajenia, wyłącznie z przyzwyczajenia” i wyznać: „Nie chodziło o to, by dojść do punktu, w którym nie mówi się już ,ja”, ale do punktu, w którym mówienie bądź nie mówienie ,ja" nie ma już żadnego znaczenia. Nie jesteśmy już sobą. Każdy rozpozna swoich. Byliśmy wspomagani, inspirowani, zwielokrotnieni" 36 . Na tej podstawie kolektywna strategia pisarska Deleuza i Guattariego daje się rozumieć jako działanie wymierzone $\mathrm{w}$ tradycyjnie pojmowaną kategorię autorstwa, będącą przejawem „korzennego" paradygmatu podmiotowego i jego „wiązkowej” modyfikacji, które zastąpić należy pluralną logiką kłącza. Ta zaś zakłada odwrót od tego, co określa się mianem "osobowego" - napisze Deluze: „Pisanie we dwóch nie stanowi więc dla nas specjalnego problemu, przeciwnie. Byłby to problem, gdybyśmy byli osobami, posiadającymi własne życie i własne opinie, decydującymi się na współpracę, dyskusję. Kiedy powiedziałem, że Félix i ja byliśmy raczej dwoma strumieniami, miałem na myśli to, że indywiduacja nie musi być koniecznie osobowa. Nie mamy wcale pewności, czy jesteśmy osobami"37.

Jeśli do pewnego momentu „roz-twarzanie” Rachwała i Sławka zgodne jest z myślą Deleuze'a i Guattariego, to różnica ujawnia się właśnie tutaj. „Pisanie we dwóch nie stanowi dla nas specjalnego problemu, przeciwnie" - powiadają Deleuze i Guattari, którym pisanie takie jest „na rękę"; wobec ich zamierzenia można wręcz określić je jako „poręczne” (filozoficznie, ideologicznie, politycznie). Natomiast Rachwałowi i Sławkowi wspólne pisanie $\mathrm{w}$ dużej mierze przeszkadza: wiąże ręce, plącze, targa, sprawia, że ich pióro bazgrze, a siła illokucyjna przekazu rozpada

33 G. Deleuze, Résponse à une question sur le sujet. Cyt. za: M. Herer, Gilles Deleuze..., s. 156.

34 Cyt. G. Deleuze, Po czym rozpoznać..., s. 324-235. Cyt. za: M. Herer, Gilles Deleuze..., s. 158.

${ }^{35}$ M. Herer, Gilles Deleuze..., s. 162.

${ }^{36}$ G. Deleuze, F. Guattari, Ktacze (1980), przeł. B. Banasiak, „Colloquia Communia", 1988, nr 1-3 (36-38), s. 221.

${ }^{37}$ G. Deleu ze, Sur la philosophie. Cyt. za: M. Herer, op. cit., s. 103. 
się. Różnicę tę da się - w moim mniemaniu - dookreślić właśnie dzięki metaforze roztworu. Deleuze i Guattari wycofują się z tekstu, w obrębie którego wskazują nieskończoną mnogość działających sił, strumieni, reakcji - umożliwiło im to przyjęcie punktu widzenia zbliżonego do perspektywy badaczy obserwujących utworzony roztwór i działających na niego coraz to nowymi związkami, przy czym nie może dojść do konfliktu, ponieważ kłączu, jakim są ich teksty, wyjdzie to tylko na dobre. Natomiast Rachwał i Sławek „roz-tworzyli” się sami, teraz zaś toną w roz-tworze swoich tekstów - w takim położeniu nie sposób kooperować i badać, trzeba zaś „roz-mawiać”: szukać ratunku, kłócić się, spierać, być w konflikcie, gniewać się, ponieważ „gniew jako reakcja właściwa przyjaźni broni ludzkości bycia”, zaś „przyjaźń jest w istotnym sensie nieporozumieniem"38. Obserwując z zewnątrz reakcje zachodzące w roztworze, nie ma się większego problemu $z$ ich opisaniem, transkrypcją na „odpowiedni” język, nie ma też różnicy, czy robi się to w pojedynkę czy kolektywnie ${ }^{39}$. Ale kiedy jest się wewnątrz, język zaczyna stanowić problem, traci bowiem swą „poręczność” (język jako narzędzie, jak u Husserla), a staje się „uniwersalnym medium”, spoza którego nie sposób wyjrzeć (jak u późnego Heideggera). Samo pisanie jest tu niełatwe, tym bardziej zaś pisanie wspólne. W tym położeniu - które spowodowane jest przyjęciem konsekwencji Derridiańskiej dekonstrukcji, nie stanowiącej pierwszorzędnego problemu dla Deleuze'a i Guattariego - wspólne pisanie jawi się jako akt par excellence etyczny (tak jak zresztą, na wyższym poziomie, uparte stawianie się w takiej właśnie sytuacji). Nie ma bowiem ani sensu, ani usprawiedliwienia, nie jest potrzebą, ani koniecznością, nie jest również przyjemnością - może stanowić jedynie akt Derridiańskiej odpowiedzialności. Ten moment, pociągający za sobą dalsze różnice (tematyka, kształt tekstu, nacechowanie ideologiczne, porządek narracji, sposób prezentacji argumentów etc.) odróżnia Rachwała i Sławka, starających się oddać sprawiedliwość dekonstrukcji - od Deleuza i Guattariego funkcjonujących na innej płaszczyźnie i kreujących inne problemy.

Tak rozumiany projekt podwójnego autorstwa Rachwała i Sławka mógłby służyć wręcz jako model tego typu krytyki etycznej, który Danu-

38 T. Sławek, Maslo i próchno/ tza. Blake i filozofia przyjaźni, „Er(r)go” 2000, nr 1, s. 67 i 69.

39 Zmienność ról „działającego" i „zapisującego" mogłaby tu być pojmowana, jak w Deleuzjańskiej interpretacji Nietzschego, jako nieustanna przemienność perspektyw: „Dopóki Nietzsche panował nad zmianą perspektywy, od zdrowia ku chorobie i na odwrót, bez względu na to, jak bardzo był chory, cieszył się „dobrym zdrowiem”, co dawało mu możliwość tworzenia". G. Deleu ze, Nietzsche (1965), przeł. B. Banasiak, Warszawa 2000, s. 21. 
ta Ulicka nazywa „retorycznym” i wiąże z patronatem Derridy i de Mana, wyodrębniając go w ten sposób od wariantu "gramatycznego", któremu patronują Wayne Booth i Martha Nussbaum, a który - jak słusznie powiada badaczka - może „śmieszyć, tumanić, przestraszać"40. Charakteryzując krytykę retoryczną i zastanawiając się na jej przyszłością, napisze Ulicka:

Dąży ona, by rzecz ująć w języku literaturoznawstwa, do zademonstrowania nieusuwalności konfliktu pomiędzy podejściem idiograficznym (interpretacyjnym) i systemowym (bliskim nomotetycznemu) - między tym, co bezwzględnie jednostkowe, związane $z$ niepowtarzalną sytuacją, na którą składają się jednokrotne zdarzenia, momentalne przeżycia i unikalne sytuacje, i tym, co w owych zdarzeniach, doświadczeniach i sytuacjach ponadindywidualne, powtarzalne, archetypiczne. Innymi słowy - zmierza do pokazania trwałej (także w postępowaniu badawczym) oscylacji między zdarzeniami i aktami zdeterminowanymi a nieprzesądzonymi, oraz do jej zachowania, nie zaś opowiadania się po jednej ze stron. Wydaje się, że od możliwości zbudowania takiego właśnie projektu zależą dalsze losy literaturoznawstwa etycznego, jeśli miałoby ono wprowadzić autentycznie nową jakość w stosunku do wcześniejszych praktyk etycznych w badaniach literackich ${ }^{41}$.

Czym innym, jeśli nie takim projektem jest koncepcja podwójnego autorstwa Rachwała i Sławka? Jeśli nieudanym, to i tak warto o nim pamiętać i wyciągnąć wnioski $\mathrm{z}$ ich porażki (być może nieuniknionej). Jeśli jednak uznamy go za udany, to przyznać będziemy musieli, że jego autorzy dokonują w nim innego roz-mieszczenia choćby takich kategorii użytych we fragmencie powyższym, jak „to, co bezwzględnie jednostkowe” (co jest jednostkowe w tekście wspólnym?) czy „niepowtarzalna sytuacja” (skoro dwie osoby nie mogą pisać jednocześnie, konieczne jest tu jej powtórzenie), które stają się $w$ analizie fenomenu podwójnego autorstwa niefunkcjonalne: podwojony idiom przestaje być idiomem, reprezentowane przez osobę współautora prawo instytucji przybiera inne oblicze, zaś tekst przestaje być „tekstem”, bo „Zmienia się modalność jego istnienia”42.

40 D. Ulicka, „Zwrot” etyczny $w$ badaniach literackich, w: Polonistyka $w$ przebudowie. Literaturoznawstwo - wiedza o języku - wiedza o kulturze - edukacja, t. I, Kraków 2006, s. $149-172$. W przyp. 32 Ulicka wymienia zresztą nazwisko Slawka jako badacza, który "wielokrotnie pisał o sprawach związanych z etyką retoryczną" (obok A. Burzyńskiej, J. Gutorowa, M. Kwieka, M.P. Markowskiego i A. Szahaja, spośród których, jak sądzę, Sławek realizuje retoryczny wzorzec krytyki etycznej najdłużej i najbardziej konsekwentnie).

41 Tamże, s. 152-153.

42 M. Foucault, Kim jest..., s. 218. A' propos nowych konfiguracji i perspektyw: jeśli Glas bywa analizowane jako hipertekst, to dlaczego nie spojrzeć na problem podwójnego autorstwa w kontekście przemian komunikacyjnych w nowych mediach? 
Tylko gdyby tak było, byłbym usprawiedliwiony przed Strzegącym Wejścia do Księgi $\mathrm{z}$ „roz-gadania” omówienia niniejszego, $\mathrm{z}$ jego „roz-metaforyzowania” z zająkliwego roz-rywania całosci słownych - które są tyleż brzydką manierą, co roz-paczliwą próbą wpisania siebie w tekst, wyprzedzenia Strażnika i jego końcowej kwestii: „To wejście było przeznaczone tylko dla ciebie. Odchodzę teraz i zamykam je"43.

${ }^{43}$ F. Kafka, Przed prawem, przeł. J. Kydryński, w: tegoż, Proces. Wyrok, Warszawa 1981 , s. 223. 